\title{
Farm economic evaluation of raspberry production
}

\author{
Apáti, F. \\ University of Debrecen, Centre for Agricultural Sciences, \\ Faculty of Applied Economics and Rural Development, Institute of Business Economics \\ H-4032 Debrecen, Böszörményi Street 138. \\ e-mail:fapati@agr.unideb.hu
}

\begin{abstract}
Summary: Hungary was considered as one of the most significant raspberry producers in the 1980'ies. The acreage and the produced quantity, however, reflected a decreasing tendency during the past two decades: the 7000 hectares existing in the year of 1990 reduced to 1500 hectares, the current territory does not reach the 500 hectares. The annual yield is only 1 to 3 thousand tons. The level of domestic fresh consumption is very low, due to the fact that it is a relatively expensive fruit for Hungarian consumers. The requirement of the processing industry is satisfied by raspberries from mainly Polish and Serbian import. These two countries belong to the biggest raspberry producing countries in the world by producing raspberries of more than 50 thousand tons. Comparing to the Hungarian production costs and yields they are able to transport their products here at a very low price, consequently they hold the prices at a low level. The profitability of the domestic raspberry production is rather unfavourable, production often shows a deficit even in orchards of good standard; furthermore the lack of labour causes an extremely great difficulty, which is an important component of the decline of the production independently from cost conditions.
\end{abstract}

Keywords: raspberry, raspberry production, economy, farm economic

\section{Introduction}

Fruit production has a highlighted role in the agriculture of Hungary, which is proved by the fact that it employs a significant number of workers, binds assets in billions of value, and accounts for 8 to $10 \%$ of the production value of plant production (Z. Kiss, 2003). Fruit production has a great significance in improving the life standard of the population in lagged behind areas having weaker natural conditions for production and in implementing rural development programs (Papp, 1999). The decline of the sector reflected in the continuous decline of quality and the technical and technological standard and even the state of productive stock deteriorated besides the decrease in quantity. In addition these negative processes new tendencies appeared during the past half decade, the use of marketable varieties, settling up-to-date, intensive orchards and technical-technological development started in Europe (Mihályka, 2004). Regarding all these the Hungarian vegetable and fruit industry does not approach its maximal performance ability at all (Lux, 2005).

Our main objective in this study is to determine the profitability and efficiency of raspberry production. The specific objectives relating to this are the followings:

- examining inputs and production cost,

- determining yield, selling price and production value,

- evaluating profit generating ability, profitability and efficiency,

- determining the major conditions of profitable raspberry production by carrying out sensitivity analysis of all these factors.

\section{Materials and methods}

The cost and benefit conditions of raspberry orchards regarded as up-to-date in Hungary will be detailed in the study. The major parameters of the orchard type serving the basis of the analysis are the following:

- annual variety called "Fertődi Zamatos" for freezing industry purposes,

- distance between rows is 2,5 to 3,0 meters, distance between plants is 0,4 to 0,5 meter, the average spacing is 8000 plants per one hectare,

- support system and drip irrigation,

- technology of harvesting is hand picking,

- the reachable yield level in normal and good years is 8 to 12 tons per one hectare,

- product: fruit being packed into plastic bins, sorted only by hand and sold right after harvesting.

Such an orchard may be characterized by yields highly exceeding the national average, good product quality (size and ripeness), high inputs, production technology of good standard and strict technological discipline. The prices and prime costs of the used inputs (materials, labour, mechanical work) reflect the price standards of nowadays. The prices of materials were considered without VAT, the wages were calculated altogether with benefits. Hourly wages were counted on the basis of 600 HUF to every used labour hour regardless the fact that whether paid or unpaid family labour worked. Selling prices were represented by a longer-term (3 to 5 years) average. 
The natural inputs of production, yields and selling prices were based on primary data gathering realized in producing enterprises, while input prices were gathered from inputdistributor firms. Data processing happened in a deterministic farm economic model. The utilized analyzing method is costbenefit analysis and the sensitivity analysis of these, where major profit, profitability and efficiency indicators of the production were investigated.

\section{Results}

\section{Production costs}

Regarding production costs, we have to start with the fact that an up-to-date raspberry orchard is able to reach a yield of about 15 tons per one hectare in the best years under domestic conditions. In the average of many years, however, we may count on a yield of 8 to 12 tons per one hectare due to mainly weather reasons. Thus cost calculations were planned for a yield of 10 tons per one hectare, which suppose a medium-good year.

The direct production cost per one hectare of raspberry production is approximately 3 million HUF regarding the previously mentioned parameters, which, supplementing with overhead costs, exceeds this value (Table 1). The cost of picking is responsible for half of the production costs, while pruning, green operations and hand hoeing take up $20 \%$. These cultivation phases cover the hand operations, which demand for labour is the following:

- pruning and green operations (cutting back canes, tying canes, removing sprouts, thinning sprouts, etc) need 800 to 1100 labour hours per one hectare,

- hoeing rows for 4 to 7 times needs 300 to 400 labour hours,

- picking needs 2300 to 2700 labour hours (2 500 labour hours in average) in case of 3,7 to $4,3 \mathrm{~kg} /$ person/hour (4,0 $\mathrm{kg}$ in average) performance and regarding a yield of 10 tons per one hectare.

On the basis of the above mentioned the labour need of raspberry production per one hectare ranges from 3400 to 4200 labour hours, by which it is considered as being the fruit production branch having the biggest labour requirement. In this way labour costs take up $70 \%$ of the production costs (Table 2).

Besides phases of manual labour there is not any further significant cost element. Ratio of the depreciation of the orchard is $10 \%$, but the other cultivation phases do not have a major effect on the production costs.

The plant protection of raspberry may be realized with 6 to 8 sprayings, and besides this herbicide for weed control is necessary once and all these constitute a plant protection cost of 200 to 250 thousand HUF per one hectare altogether with the costs of soil fumigation applied once in a year. Fertilization consists of using only artificial fertilizer with the cost of 60 to 80 thousand HUF per one hectare, the spaces between the rows are kept clear mechanically (by disc and harrow), which constitute a cost of 40 to 50 thousand HUF. Irrigation is an extremely important operation for reaching high yields, as water demand of raspberry is huge. The greater part of the cost of this operation includes depreciation of irrigation equipment (which is stated not here but among the depreciation of the orchard) and the yearly operating cost of irrigation is only 30 to 50 thousand HUF.

Table 1: The Production Cost of a Raspberry Orchard Cultivated on a Good Standard Relating to Cultivation Phases in a Good Year Regarding a Yield Level of 10 Tons per One Hectare

\begin{tabular}{|l|c|c|c|}
\hline \multirow{2}{*}{\multicolumn{1}{|c|}{ Cultivation phases }} & \multicolumn{2}{|c|}{ Production cost } & \multirow{2}{*}{$\begin{array}{c}\text { Distribu- } \\
\text { tion } \\
\text { (\%) }\end{array}$} \\
\cline { 2 - 3 } & $\begin{array}{c}\text { thousand } \\
\text { HUF/ha }\end{array}$ & HUF/kg & (5,5 \\
\hline Pruning and green operation & 480 & 48,0 & 5,8 \\
\hline Hoeing rows by hand & 180 & 18,0 & 1,4 \\
\hline $\begin{array}{l}\text { Mechanical spacing cultivation } \\
\text { (disc \& harrow) }\end{array}$ & 44 & 4,4 & 7,8 \\
\hline Plant protection & 243 & 24,3 & 2,1 \\
\hline Fertilizing & 66 & 6,6 & 1,3 \\
\hline Irrigation & 42 & 4,2 & 48,2 \\
\hline Picking & 1500 & 150,0 & 1,9 \\
\hline $\begin{array}{l}\text { Other cost (transportation, insur- } \\
\text { ance, etc.) }\end{array}$ & 60 & 6,0 & 9,6 \\
\hline Depreciation of the orchard & 300 & 30,0 & 93,6 \\
\hline Direct production cost & 2915 & 291,5 & 6,4 \\
\hline Overhead cost & 200 & 20,0 & 100,0 \\
\hline Total production cost & 3115 & 311,5 & \\
\hline
\end{tabular}

Source: own calculation

Data in Table 2 strengthen the same correlations: more than two third of the production cost is labour and benefits, the rest one third includes the other cost elements.

On the basis of the above mentioned, the prime cost per kilogram of raspberry production is approximately $300 \mathrm{HUF}$, and the following important consequences may be concluded from its cost structured feature.

- In terms of the yield, the cost of picking among the costs is a variable cost, which means that its value per hectare increase or decrease by the increase or the decrease of the yields, but whatever yield level is reached, the value per kilogram remains around 150 $\mathrm{HUF} / \mathrm{kg}$ (it changes minimally with the yield), that is it does not affect the prime cost.

- All the other costs may be more or less considered as fixed costs, thus the value per hectare is fixed independently from the yield, which means that the value per kilogram decreases by the increase of yields, and thus they reduce the prime cost. Contrary, in case of lower yields the values per kilogram rise proportionally.

- From the above mentioned, the prime cost per kilogram of raspberry is 450 to $500 \mathrm{HUF} / \mathrm{kg}$ in case of a yield of 5 tons per one hectare, while regarding an outstanding yield level of 15 tons per one hectare it is near $250 \mathrm{HUF} / \mathrm{kg}$. 
Table 2: The Production Cost of a Raspberry Orchard Cultivated on a Good Standard Relating to Cost Types in a Good Year Regarding a Yield Level of 10 Tons per One Hectare

\begin{tabular}{|l|c|c|c|}
\hline \multirow{2}{*}{\multicolumn{1}{|c|}{ Cost type }} & \multicolumn{2}{c|}{ Production cost } & \multirow{2}{*}{$\begin{array}{c}\text { Distribu- } \\
\text { tion } \\
\text { (\%) }\end{array}$} \\
\cline { 2 - 3 } & $\begin{array}{c}\text { thousand } \\
\text { HUF/ha }\end{array}$ & HUF/kg & 8,1 \\
\hline Material cost & 253 & 25,3 & 69,7 \\
\hline Labour cost & 2170 & 217,0 & 4,9 \\
\hline Machinery cost & 152 & 15,2 & 1,3 \\
\hline Other cost & 40 & 4,0 & 9,6 \\
\hline Depreciation of the orchard & 300 & 30,0 & 93,6 \\
\hline Direct production cost & 2915 & 291,5 & 6,4 \\
\hline Overhead cost & 200 & 20,0 & 100,0 \\
\hline Total production cost & 3115 & 311,5 & \\
\hline
\end{tabular}

Source: own calculation

Due to the cost structured feature of raspberry (high ratio of picking costs, which almost the same to every kilogram product being independent from the yield) by the increase of the yields significant reduction in prime costs cannot be reached: the prime cost remains within 250 to 300 HUF per one kilogram even in the best years. Regarding yield losses caused by mainly weather extremes or technological aspects, the yield of raspberry rather ranges from 5 to 10 tons per one hectare in the majority of the years in Hungary even in a good orchard than exceeding this value, thus its prime cost is between 350 and $450 \mathrm{HUF} / \mathrm{kg}$.

\section{Production value, profit, profitability}

A yield of 10 tons per one hectare in the average of several years can be expected from orchards of good standard in an average year. The selling price of raspberry for industrial processes ranged from 250 to $450 \mathrm{HUF} / \mathrm{kg}$ during the last years (the former relates to juice, the latter is for freezing industry processes), which forecasts the profit conditions of raspberry reflected in Table 3 . Its prime cost as detailed earlier ranges from 350 to 450 HUF per one kilogram, thus the production is slightly loss-making even in case of a good yield of 10 tons per one hectare especially in case of selling for juice purposes: it is true not only for net profit but even for the cash-flow as for the difference of revenues and expenses meaning the fact that the revenues are insufficient for covering the annual operating expenses. This gives an explanation for the fact that why only several hundred hectares of raspberry orchards remained in the country.

In case of an outstandingly high yield of 15 tons per one hectare only a net profit of 200 to 400 thousand HUF per one hectare may be reached, which makes the raspberry noncompetitive regarding most of the fruit species, as any of our fruit species may be characterized by more favourable profit conditions.

In case of selling for freezing industry purposes the purchase prices of 400 to 450 HUF per one kilogram result in zero profit regarding a per hectare yield of 5 tons, while in case of a yield of 10 tons per one hectare a relatively good profit may be reached (500 to 1000 thousand HUF/hectare).
The question is that how often the orchard is able to reach a yield of 10 tons per hectare or to exceed this and what ratio the product may be sold for freezing industry purposes.

Table 3: Revenue and Profitability of a Raspberry Orchard Cultivated on a Good Standard in a Good Year Regarding a Yield of 10 tons per One Hectare

\begin{tabular}{|l|l|c|}
\hline \multicolumn{1}{|c|}{ Denomination } & \multicolumn{1}{c|}{ Unit } & Value \\
\hline Yield & tons/ha & 10,0 \\
\hline Average selling price & HUF/kg & 280,0 \\
\hline Revenue & thousand HUF/ha & 2800,0 \\
\hline Direct production cost & thousand HUF/ha & 2915,0 \\
\hline Contribution & thousand HUF/ha & $-115,0$ \\
\hline Overhead cost & thousand HUF/ha & 200,0 \\
\hline Net profit & thousand HUF/ha & $-315,0$ \\
\hline Cash flow & thousand HUF/ha & $-15,0$ \\
\hline Profit to cost ratio & $\%$ & $-10,1$ \\
\hline Prime cost & HUF/kg & 311,5 \\
\hline
\end{tabular}

Source: own calculation

It is likely that the profit generating ability of raspberry sold for fresh market is much more favourable, where much higher selling prices may be reached, though the costs of production and selling will be higher as well. The limit is the fact that the market of fresh market raspberry is very narrow because it is a rather expensive fruit for the majority of the Hungarian consumers. Presumably it is not considered as a significant breaking point. This reachable profit will further improve if every work is carried out by unpaid family labourforce, by which labour cost may be saved. The size of the land which can be cultivated and harvested by a family, however, does not exceed 0,2 to 0,4 hectare.

The labour-force demand of 3500 to 4500 hours per one hectare constitute an extremely huge limitation in the development of raspberry production (and maybe it is the most serious factor withdrawing the development) and two third arises during picking in a very narrow time interval. In order to carry out the picking in one hectare 10 to 20 persons are necessary as it may be harvested in 10 to 14 picking courses, and up to 2 to 4 days are available for one course. It is a very typical situation in Hungary that so much labourforce is not available, thus the harvest cannot be carried out within the biological deadline, which may contribute to the loss of production, or even the establishment of the orchard is postponed by the farmer as a consequence.

\section{Conclusions}

On the basis of the results the major farm economic advantages and disadvantages of the raspberry are summarized as follows.

The major farm economic advantages of raspberry are:

- fast turning to productivity, short immature period after the establishment, 
- during cultivation low demand for materials and energy in the productive years,

- relatively technology may be surely solved, by this the risk from production technology is fairly low,

- fresh market selling provides a narrow market gap, but a relatively good profitability may be reached there.

The major farm economic disadvantages of raspberry are:

- comparatively high start-up capital requirement (establishment cost),

- extremely high labour demand in the productive years (3 500 to 4500 labour hours/ha), from which 70 to $80 \%$ realizes in the period of harvesting,

- among the fruit species almost the highest production cost and net working capital per one hectare

- compared to other fruit species, production risk (danger from frost, hail and drought damages) is not lower at all,

- bad profitability, often cash flow is also negative, only selling for freezing industry or fresh market purposes contribute to profit generally by reaching yield above 10 tons per one hectare,

- in case of a total crop failure, the deficit is relatively high because the fix costs of the production is high (annual operating cost of approximately 1000 thousand HUF per one hectare even in a year without any yield),

- relatively unfavourable market position, frequent selling problems.

Because of the farm economic disadvantages of raspberry above mentioned, it may not be considered as a competitive fruit species in Hungary, as most of the fruit species have more favourable characteristics relating to farm economic features, thus raspberry may not be competitive in the rivalry for land and capital within the firm.

\section{Acknowledgement}

This research was supported by the European Union and the State of Hungary, co-financed by the European Social Fund in the framework of TÁMOP-4.2.4.A/ 2-11/1-20120001 'National Excellence Program'. The identification of the application is: A2-MZPD-13-0358

\section{References}

Flock, C. (2000): Betriebszweigabrechnung in der Landwirtschaft. Verlag Pflug und Feder. Sankt Augustin, 11: 158. p.

Lux R. (2005): A kertészet fejlesztési lehetőségei Stratégiai munkaanyag, Fruitveb Magyar Zöldség-Gyümölcs Szakmaközi Szervezet Budapest.

Mihályka L. (2004): Miért szorulunk almabehozatalra? Kertészet és Szőlészet. 4: 14. p.

Papp J. (1999): Az EU-összehasonlításban versenyképes kertészeti ágazatok fejlesztési koncepciójának alapjai. [In.: Versenyképes kertészeti ágazatok fejlesztési koncepciójának alapjai - Stratégiai kutatások a Magyar Tudományos Akadémián.] (Szerk.: Papp J.) Agroinform Kiadó. Budapest, 8-14. p.

Z. Kiss, L. (2003): A gyümölcstermesztés feltételrendszere. [In.: A gyümölcs-termesztés, -tárolás, -értékesítés szervezése és ökonómiája.] (Szerk.: Z. Kiss). Mezőgazda Kiadó. Budapest, 13. p. 